Ann. Génét. Sél. Anim., I979, 11 (2), I2I-I25.

\title{
Serum protein and enzyme polymorphism and leptospirosis of pigs of Polish Large White breed
}

\author{
T. PRZYTULSKI $\left(^{*}\right)$ and D. PORZECZKOWSKA (**) \\ (*) Institute of Animal Breeding and Technology of Animal Production, \\ Academy of Agriculture, 7I-460 Szczecin, Judyma 6. (Poland) \\ (*) Vetevinary Hygiene Research Station, \\ Ostrawicka I, 7I-337 Szczecin (Poland)
}

\section{Summary}

An attempt was made to ascertain the connection between the polymorphism of blood serum proteins and enzymes - prealbumins $(P r a)$, haemopexins $(H p x)$, alkaline phosphatase $(A k p)-$ and the occurrence of leptospirosis in pigs.

Data obtained from 824 Large White pigs in two farms show that in pigs secreting Pra AB or $\mathrm{BB}$ and $A k p \mathrm{AB}$ there is a significantly lower incidence of leptospirosis infection than in pigs producing Pra AA and $A k p$ BB or BC respectively. A significantly lower incidence also appears in pigs heterozygous for $H p x$ as compared to homozygotes and a higher incidence in homozygous $H p x$ I-I as compared to the other homozygotes considered together.

\section{Introduction}

The genetic resistance to leptospirosis in pigs has been analyzed by PrzyTULSki and Porzeczkowska (I979b). The percentage of progeny with positive results from matings between resistant boars and sows was very small (2.2). The percentage of progeny with positive results from matings between susceptible boars and sows was very high (67.I).

Only a few studies are available on genetic markers of resistance to leprospirosis in animals. HoDGEs et al. (r976) analyzed the relationship of haemeglobin phenotypes with letpospirosis in sheep and they found that sheep possessing type $\mathrm{AB}$ haemoglobin exhibited more marked reaction following inoculation with pomona than those with haemoglobin types A or B. Genetic markers of resistance to leptospirosis in pigs have been analyzed by PrzYTUr.sKI and PORzECZKOWSKA (I976, I979a).

The aim of this investigation was to find differences in serological diagnosis of leptospirosis according to the phenotypes for blood serum protein and enzyme. 


\section{Material and methods}

Serum samples were chosen from the diagnostic materials of the Veterinary Hygiene Research Station. The pigs of Large White Polish breed were taken from two farms. The phenotypes or blood serum prealbumins (Pra), haemopexins $(H p x)$ and alkaline phosphatase $(A k p)$ were determined by starch gel electrophoresis according to M HESSELHOT (I969) and ZAGULSKA (I976).

The whole population was divided into two groups. The first group (I) consisted of pigs with negative leptospirosis test results while those with a positive result comprised the second group (II).

The serological test method used microscope agglutination according to the Experts' Committee Who (1967a, 1967b, r972). 4-I4 days old standard leptospira cultures were used as an antigen: RGA (icterohaemorrhagiae), Moskva V (grippotyphosa), M-84 (sejroe), Perepelicin (tarassovi), Pomona (pomona).

The results were statistically analyzed using the Chi square method, with YATES correction for continuity.

\section{Results and discussion}

The numbers of animals in each of the particular polymorphic systems in the population are presented in Table $\mathrm{I}$.

The distribution of protein and enzyme phenotypes as well as the frequencies of alleles in two farms were similar. Percentage of animals with serologically negative and those with serologically positive results in the two farms were also similar.

The frequencies of protein and enzyme phenotypes in two groups are presented in Table $\mathrm{I}$.

In this population, there were three phenotypes of prealbumins: Pra AA, Pra BB, Pra AB, determined by two codominant alleles $P r a^{\mathrm{A}}$ and $P r a^{\mathrm{B}}$. Animals possessing $\operatorname{Pra} \mathrm{AB}$ or $\mathrm{BB}$ phenotypes showed a highly significant lower $(\mathrm{P}<0.0 \mathrm{r})$ incidence of leptospirosis infection than with Pra AA (Tables I and 2).

Ten phenotypes of serum $H p x$ were present in the group I of pigs. On the other hand, six phenotypes of $H p x$ only were present in the Group II .It must be noted, that the number of animals in the second group was small (r66) in comparison to the first group (365) (Table I).

The values of $\chi^{2}$ (Table 2$)$ show a highly significant difference $(\mathrm{P}<0.00 \mathrm{r})$ between the incidence in heterozygotes and homozygotes. In the pigs showing a negative result for leptospirosis test there was a highly significant greater frequency of heterozygotes in comparison with the pigs having a positive result of leptospirosis test (Table I). A statistically highly significant difference $(\mathrm{P}<0.00 \mathrm{I})$ was also found for $H p x$ I-I, in comparison with the other homozygotes (Table 2). The pigs of $H p x$ I-I type had leptospirosis more frequently than the other homozygotes considered together. 
TABLE I

The frequencies of Pra, Hpx and Akp phenotypes in the population studied

Les fréquences des phénotypes Pra, Hpa et Akp dans la population étudiée

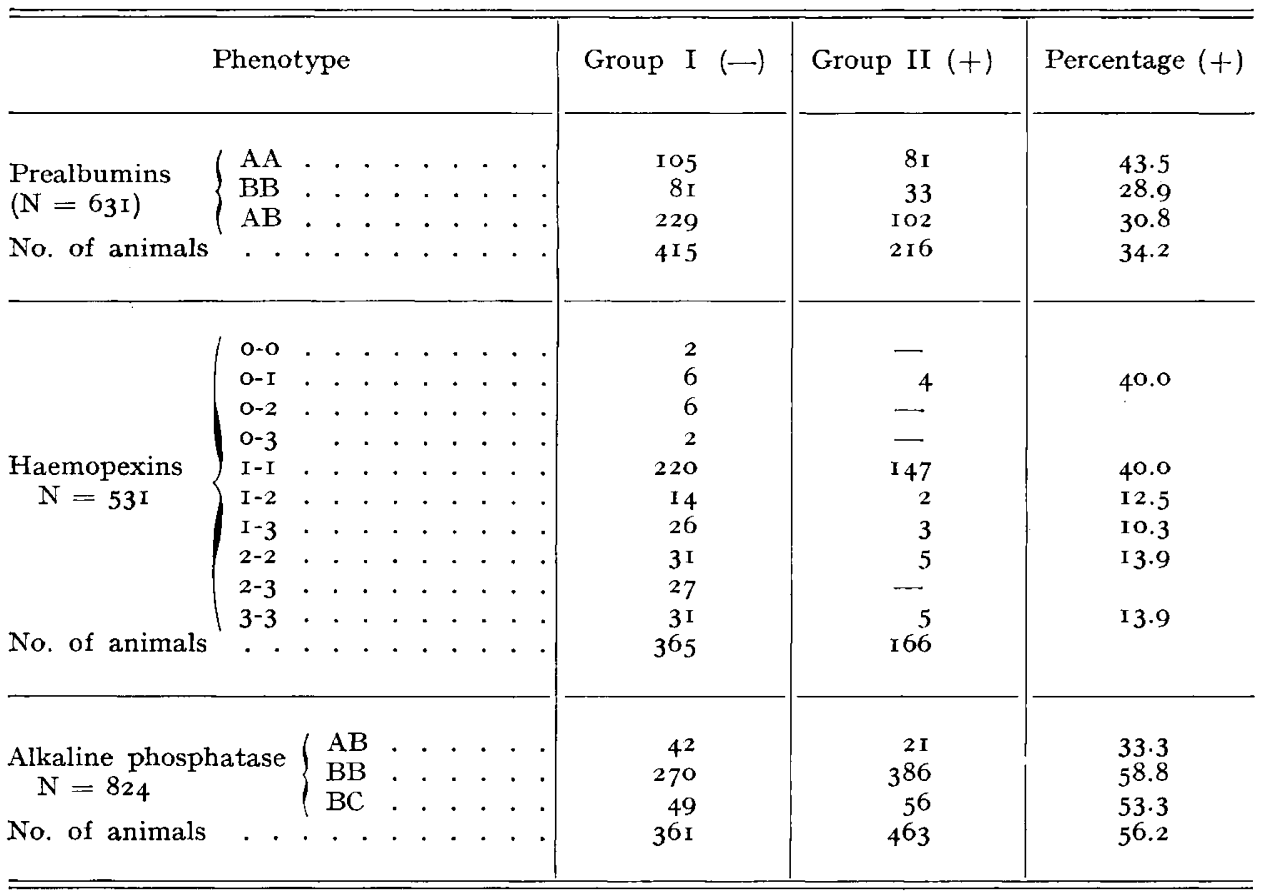

The physiological function of blood serum haemopexins indicates their main role in the processes connected with leptospirosis infection. The main function of haemopexins is the binding of free haeme as well as removal of free haeme from the blood vessels. In an earlier study of experimental Leptospira serotype pomona infection in sheep, HoDGES (I974) found that the severity of the resultant haemoglobinuria and anaemia did not appear to be related to the number of leptospirae inoculated. In the acute form of leptospirosis (more often found in cattle) anaemia, haemoglobinuria and icterus may be observed on autopsy (DrEsch et al., I976).

In the accessible literature no information concerning relationship between the physiological function of haemopexins and their phenotypes has been found.

In the population investigated the pigs showing the negative leptospirosis test had a statistically highly significant $(\mathrm{P}<0.00 \mathrm{I})$ greater frequency of $A k p \mathrm{AB}$ phenotypes in comparison with the group of pigs giving a positive results of leptospirosis test (Tables I and 2).

Generally speaking, the results of the investigations show that Pra AB or $\mathrm{BB}, A k p \mathrm{AB}$ as well as heterozygotes of $H p x$ in comparison to the homozygotes may be to some extent genetic markers of natural resistance to leptospirosis. 
TABLE 2

Significance of differences in the groups of pigs studied

Signification des différences dans les groupes de porcs étudiés

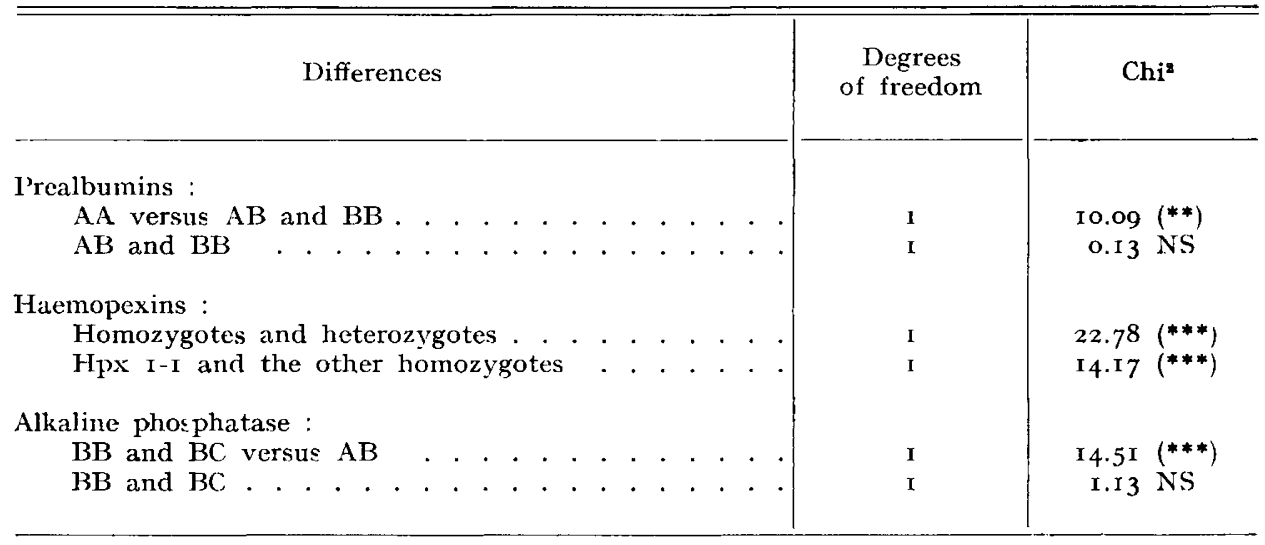

NS : Not significant.

(**) Significant at 0.0 r level.

$(* * *)$ Significant at 0.00 r level.

Likewise, in pigs secreting $H p x$ I-I there is a significantly higher incidence of leptospirosis infection than in pigs producing the other homozygotes of $H p x$.

This preliminary investigation also indicates the extremely important role which genetic typing of pigs could play as a supplementary measure in the control of leptospirosis. Genetic typing could be put to increased practical use if it were possible to develop a system of typing sows, piglets and boars to permit early elemination of animals which are genetically predisposed to infection leptospirosis.

According to different authors (WHo, I967a, I967b, I972; MrchNA, I967) the reaction microscope agglutination with living antigens is sensitive and specific, as little as r:roo titre being taken up as indicator of infection.

In the population studied the level of leptospira antibodies in seroreagents was contained within the limits of titre from: I:I00 to I:I 2800 .

It must be noted, that in case of germ carrying, as well as during the acute phase of disease, the agglutination test may result in a low or negative reaction (Sullivan, I974).

Taking advantage of the fact that leptospira antibodies remain in blood serum months or years after infection, the serological test help us indentify both the animals being in an active form of infection and those being in a retrospective one (Sullivan, r974; Turner, I967, I968).

A confirmation carried on Large White pigs, for which leptospirosis has been clinically and bacteriologically stated, would also be a supplement to the results of our work. 


\section{Acknowledgment}

We are grateful to Dr L. Ollivier (Station de Génétique quantitative et appliquée, I.N.R.A., Centre national de Recherches zootechniques, France) for reading the manuscript, and the constructive criticisms of this manuscript.

\section{Résumé}

\section{Polymorphisme de protéines et enzymes sériques et leptospirose chez des porcs Large White en Pologne}

Un essai a été entrepris pour établir la relation entre la leptospirose et des polymorphismes de protéines et d'enzymes sériques, préalbumines $(P r a)$, haemopoxines $(H p x)$ et phosphatase alcaline $(A k p)$. Les données recueillies sur 824 porcs Large White dans deux élevages montrent que l'incidence de l'infection par leptospirose est significativement plus basse chez les porcs produisant Pra $A B$ ou $B B$ et $A k p A B$ que chez ceux qui produisent Pra $A A$ et $A k p B B$ ou $B C$ respectivement. I'incidence est significativement plus faible aussi chez les hétérozygotes pour $H p x$ comparés aux homozygotes, et, chez ces derniers, l'incidence est plus élevée chez les $H p x$ $I-I$ que dans l'ensemble des autres homozygotes.

\section{References}

Diesch S. L., Glosser J. W., Hanson L. E., Morter R. L., Smith R. E., Stoenner H. G., I976. Leptospirosis of domestic animals. Agric. Inform. No. 394, Agric. Res. Ser., US Dep. Agric.

Hesselyolt M., I969. Serum protein polymorphism in swine. Munksgaard, Copenhagen.

Hodges R. T., 1974. Some observations on experimental Leptospira serotype pomona infection in sheep. N. Z. vet. J., 22, I 5 I-I 54 .

Hodges R. T., Miliar IK. R., Revfeim K. J., I976. The effects of Leptospira serotype pomona in sheep of different haemoglobin types. N. Z. vet. J., 24, 163-166.

Joint FAO/WHO Expert Committee on Zoonoses: Third Report WId. Hlth Org. Techn. Rep. Ser., 387 , I76a - see also WHO.

Michna S. W., 1967. Animal leptospirosis in the British Isles - a serological survey. Vet. Rec., 80, 394-4OI.

Przytulski T., Porzeczkowska D., 1976. Polymorphism of blood serum amylase and leptospirosis of pigs of Large White Polish breed. Theoret. Appl. Genet., 48, 237-242.

Przytulski T., Porzeczkowska D., 1979a. Polymorphism of blood serum amylase and transferrin and leptospirosis in Large White Polish pigs. Br. vet. J., 135, 103-107.

Przytulski T., Porzeczkowska D., I979b. Studies on genetic resistance to leptospirosis in pigs (in press).

Sullivan N. D., I974. Leptospirosis in animals and man. Aust. Vet. J., 50, $216-223$.

Turner L. H., 1967. Leptospirosis I. Trans. R. Soc. Trop. Med. Hyg., 61, 842.

Turner L. H., I968. Leptospirosis II. Trans. R. Soc. Trop. Med. Hyg., 62, 88o.

WHO Expert Group Wld. Hlth Org., I967. Current problems in leptospirosis. Techn. Rep., ser. 380 .

WHO Expert Group Bull. Wld. Hlth Org., I972. Research needs in leptospirosis, 47, I I3-I 22.

ZAGULSKA A., I976. Electrophoretic polymorphism of allaline phosphatase in pigs of the pied Zlotnik race (in polish). VI meet. Pcl. genet. Assoc. 